Paper ini merupakan versi bahasa indonesia dari paper kami berjudul "Allogenic River in the Hydrogeological System of Gremeng Cave, Gunungsewu Karst Area, Java Island, Indonesia" yang dipresentasikan dalam The $1^{\text {st }}$ international conference on Environment, Sustainability Issues and Community Development (INCRID) 2019, yang diselenggarakan oleh Universitas Diponegoro pada tanggal 23-24 Oktober 2019.

\title{
Sungai Alogenik di Sistem Hidrogeologi Gua Gremeng, Kawasan Karst Gunungsewu, Indonesia
}

\author{
Ahmad Cahyadi ${ }^{1,2^{*}}$, Eko Haryono ${ }^{1,2}$, Tjahyo Nugroho Adji ${ }^{1,2}$, M Widyastuti ${ }^{1,2}$, \\ Indra Agus Riyanto ${ }^{2,3}$, Muhammad Naufal ${ }^{1,2}$, Fajri Ramadhan ${ }^{1,2}$ \\ ${ }^{1}$ Department of Environmental Geography, Faculty of Geography, Universitas \\ Gadjah Mada \\ ${ }^{2}$ Karst Research Group, Faculty of Geography, Universitas Gadjah Mada, Indonesia \\ ${ }^{3}$ Master Program on Planning and Management of Coastal Area and Watershed, \\ Faculty of Geography, Univeristas Gadjah Mada, Indonesia \\ Email: ahmadcahyadi@geo.ugm.ac.id
}

\begin{abstract}
Sungai alogenik memiliki peranan yang penting dalam perkembangan kawasan karst. Sistem terbuka dari sungai alogenik memungkinkan kondisi yang agresif untuk melarutkan, sehingga imbuhan dari sungai alogenik akan menyebabkan terjadinya pelarutan batuan yang lebih intensif dan mungkin membentuk sistem sungai bawah utama dalam sebuah sistem hidrogeologi. Penelitian ini bertujuan untuk menginventarisasi sungai alogenik di sistem hidrogeologi Gua Gremeng serta menganalisis tipenya berdasarkan kondisi geologi yang menyebabkannya terbentuk. Penelitian dilakukan dengan menganalisis peta rupa bumi Indonesia, peta geologi dan citra penginderaan jauh resolusi tinggi. Selain itu, dilakukan pula survei geologi detail untuk menganalisis penyebab kemunculan sungai alogenik di lokasi kajian berdasarkan pada karakteristik geologi dan geomorfologinya. Hasil kajian menunjukkan bahwa setidaknya terdapat 5 sub sistem sungai alogenik yang bergabung menjadi satu sistem utama sungai alogenik. Tipe sungai alogenik yang muncul adalah Allogenic from underlying beds exposed updip. Kemunculan sungai alogenik tepat pada kontak batuan vulkanik tersier dan batuan gamping di kawasan karst Gunungsewu.
\end{abstract}

\section{Introduction}

Kawasan karst dikenal sebagai bentang alam yang sering mengalami permasalahan kekeringan. Di sisi yang lain, kawasan karst juga dikenal sebagai tendon air yang dimanfaatkan oleh sekitar $25 \%$ penduduk dunia [1]. Kondisi demikian disebabkan karena berkembangnya lorong-lorong pelarutan yang membentuk sistem sungai bawah tanah [2]. Hal tersebut menyebabkan kondisi kontras berupa kondisi kering di bagian permukaan tanah dan kondisi banyak air di bagian bawah permukaan [3].

Imbuhan airtanah di kawasan karst secara garis besar berasala dari dua tipe imbuhan, yakni imbuhan alogenik dan imbuhan autogenik $[4,5,6]$. Imbuhan alogenik adalah imbuhan airtanah di kawasan karst yang berasal dari kawasan non-karst. Imbuhan ini berasal dari sungai permukaan di luar kawasan karst yang masuk ke dalam sistem sungai bawah tanah melalui ponor. Berbeda dengan hal tersebut, imbuhan autogenik adalah imbuhan yang berasal dari kawawasan karst itu sendiri. Imbuhan ini berasal dari hujan yang jatuh di kawasan karst yang masuk ke dalam sistem sungai bawah tanah melalui proses infiltrasi, perkolasi, dan melalui diaklas serta lorong-lorong pelarutan yang terbentuk di kawasan karst.

Pemahaman terkait dengan karakteristik sungai alogenik (imbuhan alogenik) sangat penting dilakukan mengingat sistem sungai ini memiliki peranan yang besar dalam mensuplai airtanah di 
Paper ini merupakan versi bahasa indonesia dari paper kami berjudul "Allogenic River in the Hydrogeological System of Gremeng Cave, Gunungsewu Karst Area, Java Island, Indonesia" yang dipresentasikan dalam The $1^{\text {st }}$ international conference on Environment, Sustainability Issues and Community Development (INCRID) 2019, yang diselenggarakan oleh Universitas Diponegoro pada tanggal 23-24 Oktober 2019.

kawasan karst $[7,8,9,10,11,12,13]$. Sistem sungai alogenik juga memiliki sistem terbuka yang memungkinkan masuknya karbondioksida dari udara selama mengalir di permukaan tanah, sehingga imbuhan alogenik seringkali bersifat lebih agresif dibandingkan dengan imbuhan autogenik dalam melarutkan batuan gamping $[14,15,16]$. Kondisi ini menyebabkan imbuhan alogenik berperan besar dalam membentuk sistem sungai bawah tanah utama di kawasan karst [17]. Urgensi pengelolaan sistem sungai alogenik yang lain adalah terkait dengan kerentanan terhadap pencemaran yang tinggi pada imbuhan alogenik [18]. Hal ini karena air mengalir pada sistem terbuka dan masuk ke sungai bawah tanah tanpa mengalami proses penyaringan oleh tanah dan atau pori-pori batuan.

Penelitian ini bertujuan untuk menginventarisasi sungai-sungai alogenik di sistem hidrogeologi Gua Gremeng yang merupakan salah satu sumber mataair penting di Kabupaten Gunungkidul [19, 20, 21] (Gambar 1). Selain itu, penelitian ini juga bertujuan untuk menganalisis tipenya berdasarkan kondisi geologi yang menyebabkannya terbentuk. Hasil kajian ini diharapkan dapat memberikan masukan dalam pengelolaan kawasan karst di lokasi kajian secara umum dan pengelolaan sistem hidrogeologi Gua Gremeng secara khusus.

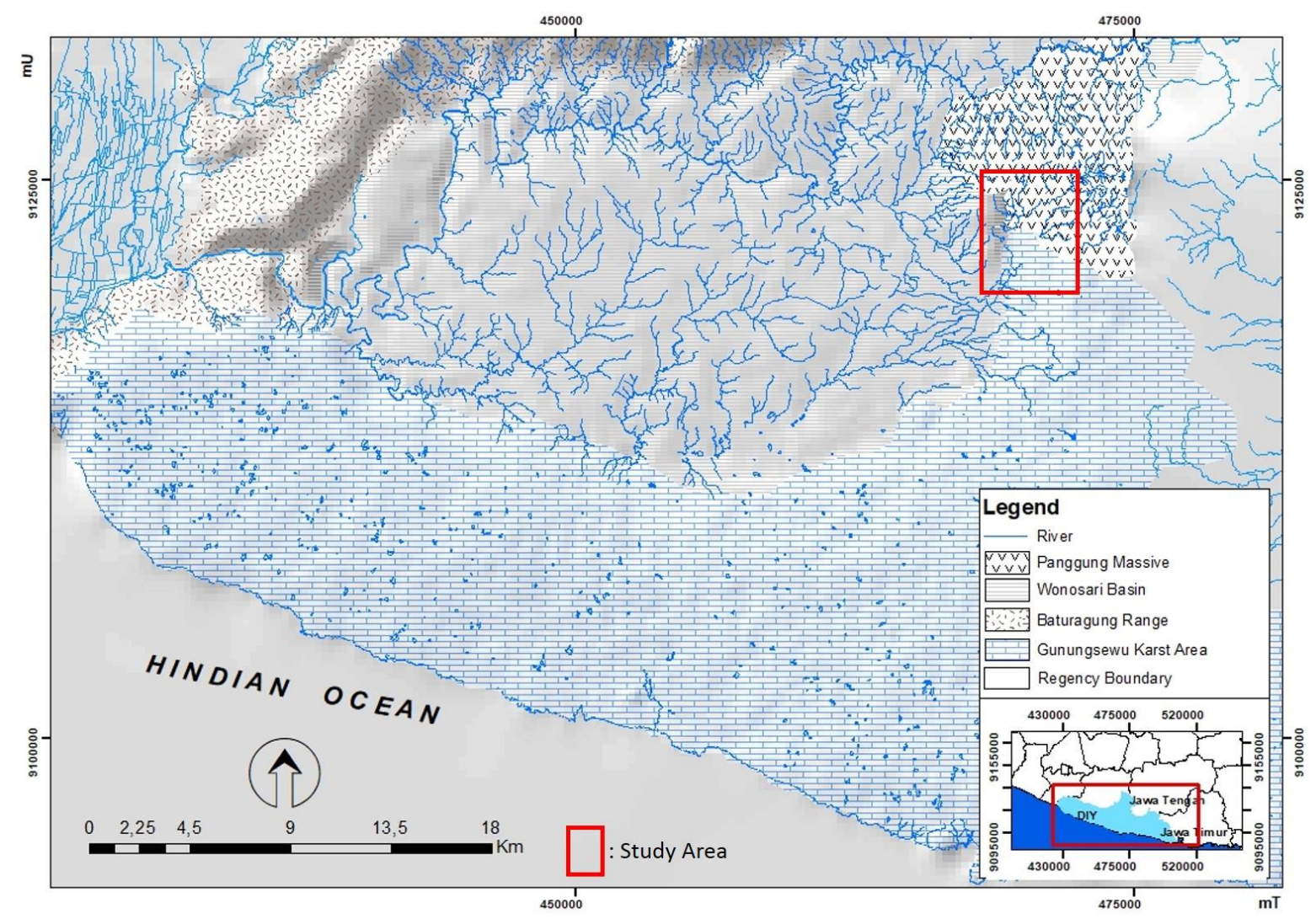

Gambar 1. Lokasi Penelitian.

\section{Methods}

Inventarisasi sungai-sungai alogenik dilakukan dengan pemetaan detail dengan menggunakan peta Rupa Bumi Indonesia (RBI) pada skala 1:25.000 dan citra resolusi tinggi berupa citra GeoEyes. Hasil interpretasi tersebut kemudian divalidasi melalui survei lapangan detail. Tipe sungai alogenik kemudian dianalisis kondisi geologi dan geomorfologinya untuk mengetahui genensis dari sungai alogenik di lokasi kajian. Tipe sungai alogenik kemudian diklasifikasikan berdasarkan klasifikasi Ford and Williams (2007) [1]. Tiga tipe sungai alogenik berdasarkan genesisnya menurut Ford and Williams 
Paper ini merupakan versi bahasa indonesia dari paper kami berjudul "Allogenic River in the Hydrogeological System of Gremeng Cave, Gunungsewu Karst Area, Java Island, Indonesia" yang dipresentasikan dalam The $1^{\text {st }}$ international conference on Environment, Sustainability Issues and Community Development (INCRID) 2019, yang diselenggarakan oleh Universitas Diponegoro pada tanggal 23-24 Oktober 2019.

(2007) [1] meliputi (1) allogenic from overlying beds, (2) allogenic from underlying beds exposed updip, dan (3) across a faulted contact with impervious rocks.

\section{Results and Discussion}

Hasil interpretasi dan survei lapangan menunjukkan bahwa Sistem Hidrogeologi Gua Gremeng memiliki lima sungai alogenik. Kelimanya membentuk satu sungai utama yang mengalir menuju ke Gua Gremeng. Kelima sungai tersebut dalam peta rupa bumi Indonesia (Indonesian topographic map) dan citra satelit GeoEyes nampak sebagai aliran sungai yang terputus dan tidak tersambung dengan sungai lainnya. Kelima sungai alogenik tersebut adalah Sungai Garuda, Sungai Grembel, Sungai Seropan, Sungai Kalimati, dan Sungai Sumurup. Keberadaan sungai alogenik, ponor dan resurgence di Sistem Hidrogeologi Gua Gremeng disajikan pada Gambar 2.

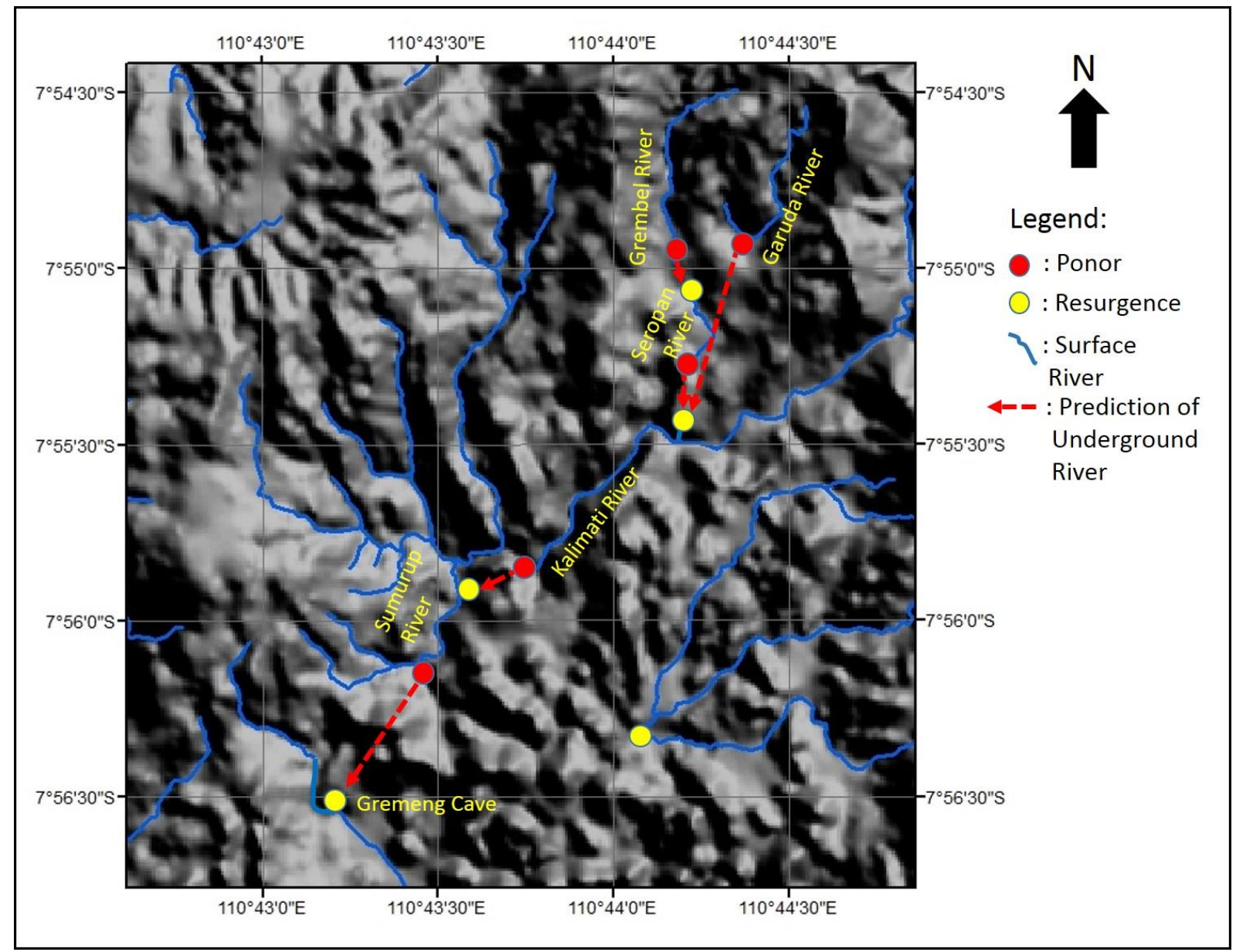

Gambar 2. Sistem sungai alogenik di Sistem Hidrogeologi Gua Gremeng.

Karakteristik aliran dari sungai-sungai alogenik di Sistem Hidrogeologi Gremeng bervariasi. Empat sungai selain sungai Sumurup hanya mengalir pada musim penghujan (Gambar 3), sedangkan Sungai Sumurup mengalir sepanjang tahun. Meskipun demikian, debit saat musim hujan cukup besar karena memiliki tangkapan yang luas. Selain itu, karakteristik bagian hulu berupa material vulkanik tua dengan dominasi batuan andesitic-basaltik menyebabkan kemampuan menyimpan air sangat rendah, sehingga hujan lebih banyak menjadi limpasan permukaan ketika musim penghujan. 
Paper ini merupakan versi bahasa indonesia dari paper kami berjudul "Allogenic River in the Hydrogeological System of Gremeng Cave, Gunungsewu Karst Area, Java Island, Indonesia" yang dipresentasikan dalam The $1^{\text {st }}$ international conference on Environment, Sustainability Issues and Community Development (INCRID) 2019, yang diselenggarakan oleh Universitas Diponegoro pada tanggal 23-24 Oktober 2019.

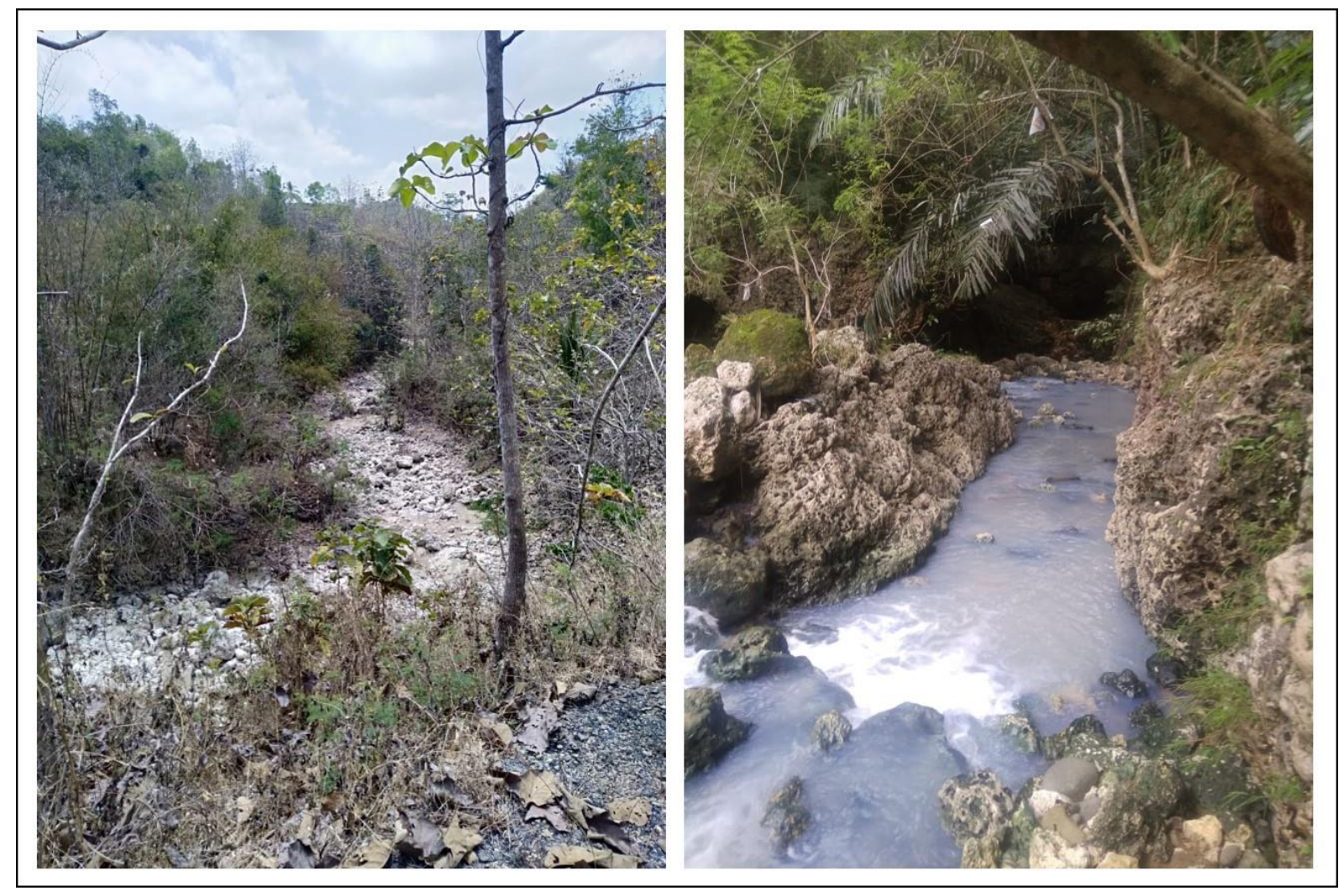

Gambar 3. Sungai Alogenik Kalimati pada musim kemarau (kiri) dan pada musim penghujan (kanan)

Munculnya sungai alogenik di lokasi kajian tidak terlepas dari genesis wilayah tersebut. Formasi gamping di lokasi kajian menunpang pada formasi vulkanik tua berumur tersier [22]. Material vulkanik didominasi material basaltic-andesitik yang dihasilkan pada masa miosen akhir [23, 24, 25]. Gunungapi yang menghasilkan material tersebut adalah Gunungapi Purba Panggung Masif Gunungapi Purba Wuryantoro dan Gunungapi Purba Wonodadi [26]. Sebagian tubuh gunungapi purba ini masih nampak di bagian utara kawasan karst Gunungsewu membentuk Fisografi Panggung Masif [27].

Kontak antara keduanya misalnya nampak dengan jelas pada Gambar 4. Gambar 4 diambil dari Ponor Garuda, yakni salah satu ponor di bagian Utara Sistem Hidrogeologi Gua Gremeng. Pada lokasi tersebut nampak batu gamping menumpang di bagian atas dari material vulkanik berupa sandstone. Perkebangan lorong gua pada lokasi ini memiliki dip yang sama dengan kemiringan batuan pada zona kontak tersebut.

Berdasarkan pada karakteristik penggunaan lahan di daerah aliran sungai alogenik pada lokasi kajian, pencemaran utamanya akan terjadi karena limbah domestik dan aktivitas pertanian [28]. Meskipun demikian, aktivitas pertanian akan menjadi penyebab utama pencemaran karena penggunaan lahan inilah yang paling dominan terdapat di lokasi kajian. Lahan pertanian pada lokasi kajian umumnya berupa tegalan (Gambar 5) dan sawah tadah hujan. Penggunaan pupuk dan pestisida pada aktivitas pertanian yang berlebihan dapat menyebabkan air yang masuk ke sungai bawah tanah Sistem Hidrgeologi Gremeng menjadi tercemar. 
Paper ini merupakan versi bahasa indonesia dari paper kami berjudul "Allogenic River in the Hydrogeological System of Gremeng Cave, Gunungsewu Karst Area, Java Island, Indonesia" yang dipresentasikan dalam The $1^{\text {st }}$ international conference on Environment, Sustainability Issues and Community Development (INCRID) 2019, yang diselenggarakan oleh Universitas Diponegoro pada tanggal 23-24 Oktober 2019.

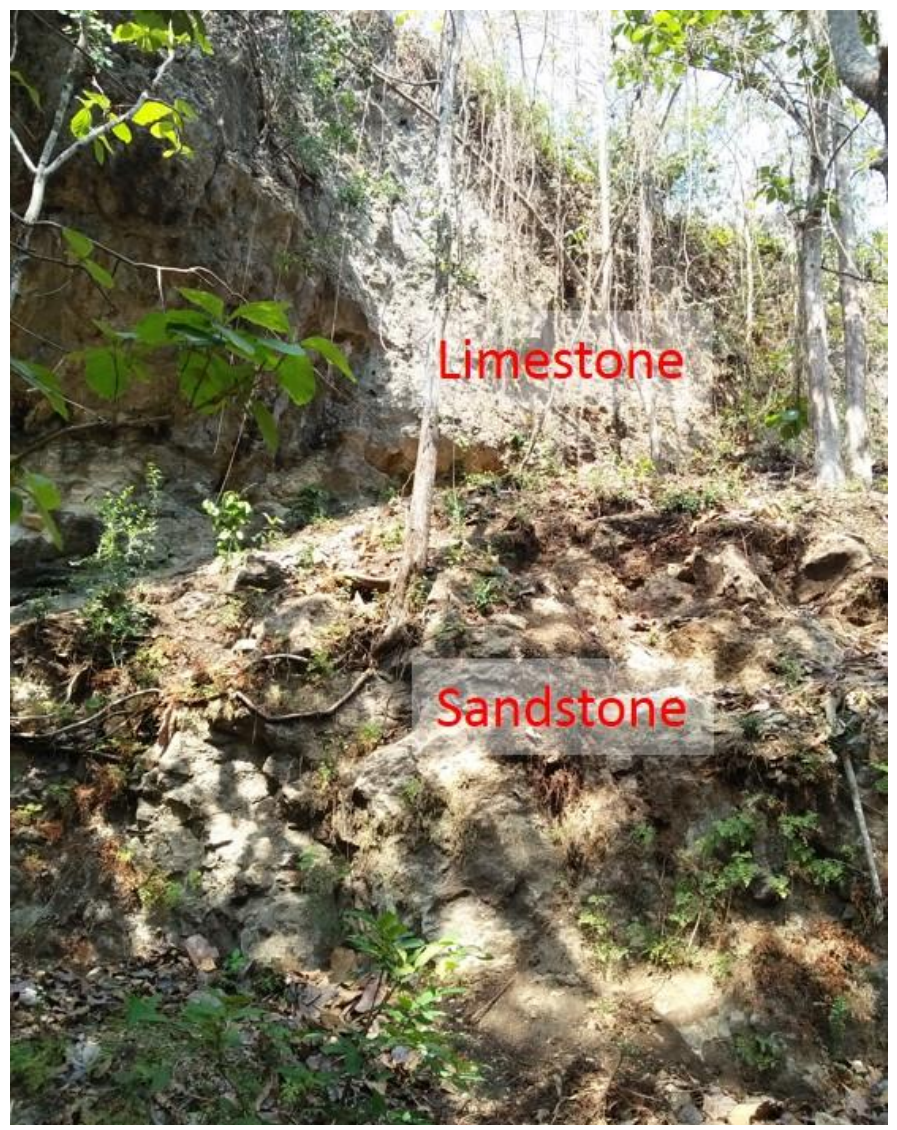

Gambar 4. Kontak batuan gamping dengan sandstone di dekat ponor yang menjadi outlet Sungai Garuda.

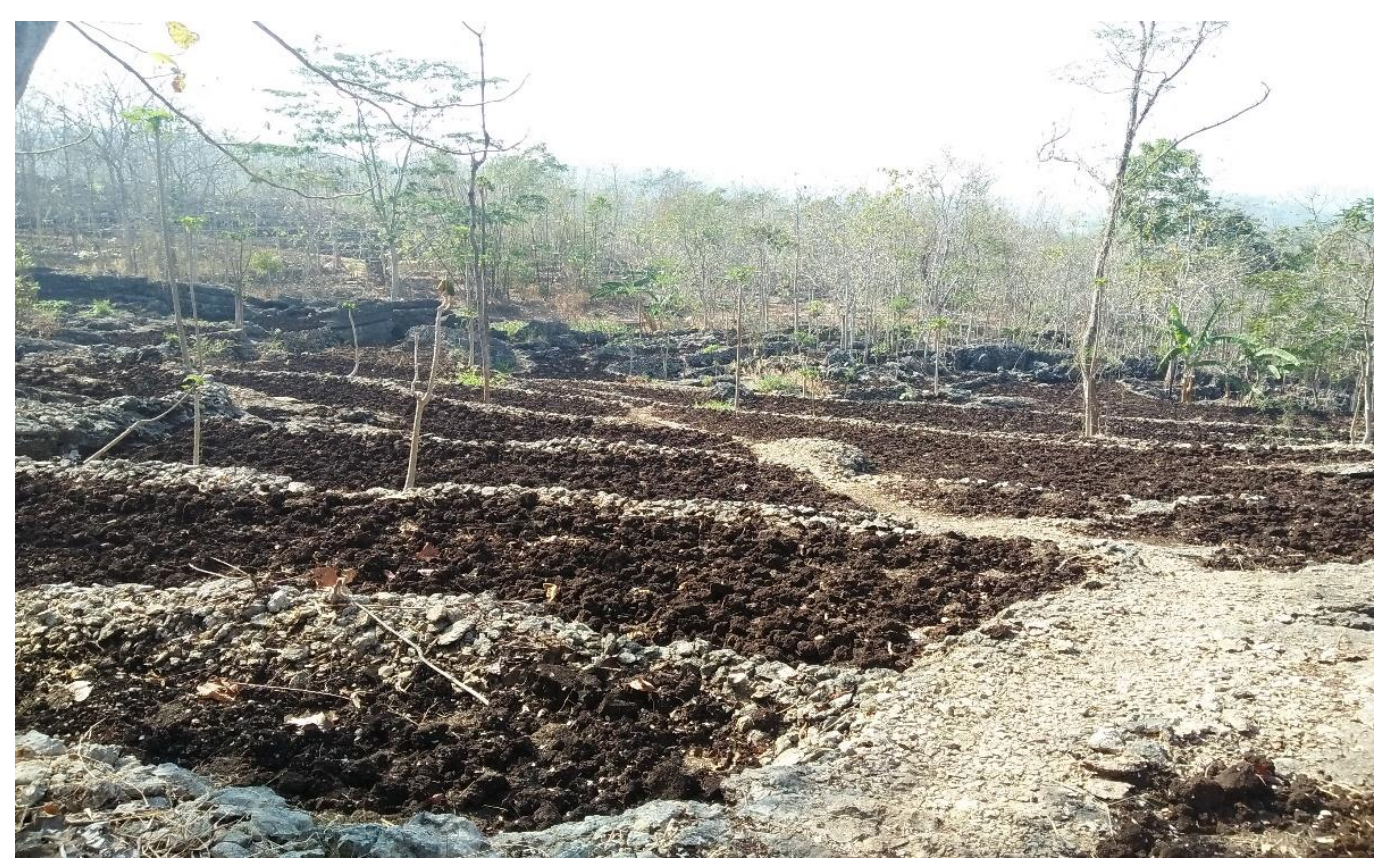

Gambar 5. Pemanfaatan lahan pertanian pada wilayah hulu dari sungai alogenik di Sistem Hidrogeologi Gua Gremeng 
Paper ini merupakan versi bahasa indonesia dari paper kami berjudul "Allogenic River in the Hydrogeological System of Gremeng Cave, Gunungsewu Karst Area, Java Island, Indonesia" yang dipresentasikan dalam The $1^{\text {st }}$ international conference on Environment, Sustainability Issues and Community Development (INCRID) 2019, yang diselenggarakan oleh Universitas Diponegoro pada tanggal 23-24 Oktober 2019.

\section{Conclusion}

Penelitian ini menginventarisasi 5 sub sistem sungai alogenik yang bergabung menjadi satu sistem utama sungai alogenik di Sistem Hidrogeologi Gua Gremeng. Kelima sungai alogenik adalah Sungai Sumurup, Sungai Kalimati, Sungai Garuda, Sungai Seropan, Sungai Grembel. Tipe sungai alogenik yang muncul di lokasi kajian adalah Allogenic from underlying beds exposed updip. Kemunculan sungai alogenik tepat pada kontak batuan vulkanik tersier (Gunungapi Purba Wuryantoro, Panggung Masif dan Wonodadi) dengan batuan gamping di kawasan karst Gunungsewu.

\section{Acknowledgement}

This research is part of the first author's dissertation and is funded by the 2019 Research Grant for Young Lecturers of Universitas Gadjah Mada. Authors would like to thank all parties who have assisted in this research.

\section{References}

[1] Ford, D. and Williams, P. 2007. Karst Hydrology and Geomorphology. Chichester, West Sussex: John Wiley and Sons, Ltd.

[2] Cahyadi, A and Agniy, R.F. 2016. Analisis Breakthrough Curve untuk Karakteristerisasi Pelorongan di Sistem Sungai Bawah Tanah Pindul Kabupaten Gunungkidul. Proceeding of Pertemuan Ilmiah Tahunan Ke-1 Perhimpunan Ahli Airtanah Indonesia (PIT-PAAI). Bandung, November 16-17, 2016, $375-385$.

[3] Widyastuti, M., Cahyadi, A., and Sasongko, MHD. 2016. Hidrologi dan Hidrogeologi Karst. In Haryono, E. 2016. Pedoman Praktis Survei Terintegrasi Kawasan Karst. Yogyakarta: Badan Penerbit Fakultas Geografi, Universitas Gadjah Mada.

[4] White, W.B. 1988. Geomorphology and Hydrology of Karst Terrains. New York: Oxford University.

[5] Field, M.S. 2005. Tracer-Test Design for Losing Stream-Aquifer Systems. International Journal of Speleology, 35(1): 25-36.

[6] Gilli, E. 2015. Karstology - Karst, Caves and Springs: Elements of Fundamental and Applied Karstology. Boca Raton: CRC Press.

[7] Worthington, S.R.H. 2011. Management of Carbonate Aquifers. In van Beynen, P.E. (ed). 2011. Karst Management. Dordrecht: Springer.

[8] Adji, T.N. 2011. Pemisahan Aliran Dasar Bagian Hulu Sungai Bribin pada Aliran Gua Gilap, di Kars Gunungsewu, Gunung Kidul, Yogyakarta. Jurnal Geologi Indonesia, 6 (3), 165-175.

[9] Adji, T.N. 2012. Wet Season Hydrochemistry of Bribin Cave in Gunungsewu Karst, Indonesia. Environ Earth Sciences, 67:1563-1572.

[10] Agniy, RF., Adji, TN., Cahyadi, A., Nurkholis, A., and Haryono, E. 2019. Characterizing the Cavities of Anjani Cave in Jonggrangan Karst Area, Purworejo, Central Java, Indonesia. IOP Conference Series: Eart and Environmental Science, 256(1): 012009.

[11] Nurkholis, A., Adji, TN., Haryono, E., Cahyadi, A., Waskito, WA., Fathoni, H., Kurniawan, IA., Agniy, RF. 2019. Analysis of Master Recession Curve (MRC) and Flood Hydrograph Components for Karstification Degree Esrimation in Kuskendo Cave, Jonggrangan Karst System, Indonesia. IOP Conference Series: Eart and Environmental Science, 256(1): 012011.

[12] Nurkholis, A., Adji, TN., Haryono, E., Cahyadi, A. and Suprayogi, S. 2019. Time Series Analysis Application for Karst Aquifer Characterisation in Pindul Cave Karst System, Indonesia. Acta Carsologica, 48(1): 69-84.

[13] Kurniawan, IA., Adji, TN., Nurkholis, A., Haryono, E., Fatoni, H., Waskito, WA., Cahyadi, A. and Agniy, RF. 2019. Karst Aquifer Response by Time Series Analysis Application in Jonggrangan Karst, java Island, Indonesia. Environmental Earth Sciences, 78(13): 379. https://doi.org/10.1007/s12665-019-8386-x

[14] Hess, J.W. and White, W.B. 1989. Chemical Hydrology. In White, W.B. and White, E.L (eds). 1989. Karst Hydrology: Concepts from the Mammoth Cave Area. New York: Springer. [16] Auler, 
Paper ini merupakan versi bahasa indonesia dari paper kami berjudul "Allogenic River in the Hydrogeological System of Gremeng Cave, Gunungsewu Karst Area, Java Island, Indonesia" yang dipresentasikan dalam The $1^{\text {st }}$ international conference on Environment, Sustainability Issues and Community Development (INCRID) 2019, yang diselenggarakan oleh Universitas Diponegoro pada tanggal 23-24 Oktober 2019.

A.S. 2013. Sources of Water Aggressiveness - The Driving Forces of Karstification. in Shroder, J.F. (ed). 2013. Treatise on Geomorphology. London: Elsevier, Inc.

[15] Palmer, A.N. 2001. Dynamics of Cave Development by Allogenic Water. Acta Carsologica, 30(2): 13-32.

[16] Riyanto, I.A., Cahyadi, A., Adji, T.N., Haryono, E., Widyastuti, M., Agniy, R.F., Fathoni, W.A., Rahmawati, N., and Baskoro, H. 2018. Analisis Konektivitas dan Karakterisasi Pelorongan dengan Uji Perunutan pada Mataair Epikarst Sub-sistem Panggang, Kawasan Karst Gunungsewu. Proceedings of the Annual Scientific Week organized by Perhimpunan Ahli Airtanah Indonesia (PAAI) in Aryaduta Hotel, Jakarta, 7-8 November 2018.

[17] Palmer, A.N. 2007. Cave Geology. Dayton, Ohio: Caves Books.

[18] Pratiwi, E.S. 2013. Kelemahan dan Kendala Penerapan Metode EPIK dalam Menentukan Zonasi Kerentanan Airtanah Intrinsik di Kawasan Karst Gunungsewu, Indonesia. In Sudarmadji, Haryono, E., Adji, T.N., Widyastuti, M., Harini, R., Nurjani, E., Cahyadi, A. and Nugraha, H. 2013. Ekologi Lingkungan Kawasan Karst Indonesia: Menjaga Asa Kelestarian Kawasan Karst Indonesia. Yogyakarta: Deepublish.

[19] Haryono, E. 2011. Introduction to Gunungsewu Karst. Field Guide of Asian Trans-Disciplinary Karst Conference. Yogyakarta: Karst Research Group, Faculty of Geography, Universitas Gadjah Mada.

[20] Lestari, Y., Haryono, E. and Fatchurohman, H. 2014. Identifikasi Tingkat Kekritisan Daerah Tangkapan Air sebagai Penentuan Arahan Pengelolaan: Studi Kasus Daerah Tangkapan Mataair Beton, Ponjong, Gunungkidul. In Cahyadi, A., Prabawa, B.A., Tivianton, T.A. and Nugraha, H. 2014. Ekologi Lingkungan Kawasan Karst Indonesia: Menjaga Asa Kelestarian Kawasan Karst Indonesia, Second Edition. Yogyakarta: Deepublish.

[21] Hayono, E.; Barianto, D.H. and Cahyadi, A. 2017. Hidrogeologi Kawasan Karst Gunungsewu: Fieldtrip Guide of $2^{\text {nd }}$ PAAI Congress. Yogyakarta: Perhimpunan Ahli Airtanah Indonesia (PAAI).

[22] Surono, B.T.; Sudarno, I. and Wiryosujono, S. 1992. Geology of the Surakarta-Giritontro Quadrangles, Java, scale 1:100,000. Bandung: Geological Research and Development Center.

[23] Marwanto, H., Subandrio, A., Riyanto, A.B.N. and Suharsono. 1999. Study of The Trace of Ancient Solo River in The Southern Wonogiri, Central Java. Yogyakarta: Universitas Pembangunan Nasional Veteran, Yogyakarta.

[24] Akmaluddin, D.L. Setijadji, K. Watanabe and T. Itaya. 2005. New Interpretation on Magmatic Belts Evolution during the Neogene-Quaternary Periods as Revealed from Newly Collected K-Ar Ages from Central-East Java - Indonesia. Proceeding of Joint Convention IAGI-HAGI-PERHAPI, Surabaya 2005.

[25] Surono. 2008. Sedimentasi Formasi Semilir di Desa Sendang, Wuryantoro, Wonogiri, Jawa Tengah. Jurnal Sumber Daya Geologi, 28(1): 29-41.

[26] Bronto, S.; Mulyaningsih, S.; Hartono, G., and Astuti, B. 2009. Waduk Parangjoho dan Songputri: Alternatif Sumber Erupsi Formasi Semilir di Daerah Eromoko Kabupaten Wonogiri, Jawa Tengah. Jurnal Geologi Indonesia, 4(2): 79 - 92.

[27] van Bemmelen, R.W. 1949. The Geology of Indonesia, Vol. 1A, General Geology. The Hague: Martinus Nijhoff.

[28] Cahyadi, A.; Riyanto, I.; Irshabdillah, M.R. and Firizqi, F. 2018. Inventarisasi dan Karakterisasi Sistem Aliran Sungai Alogenik di Kawasan Karst Gunungsewu Kabupaten Gunungkidul. Research Report. Yogyakarta: Faculty of Geography, Universitas Gadjah Mada. 